\title{
BIBECHANA
}

ISSN 2091-0762 (Print), 2382-5340 (Online)

Journal homepage: http://nepjol.info/index.php/BIBECHANA

Publisher: Department of Physics, Mahendra Morang A.M. Campus, TU, Biratnagar, Nepal

\section{Simulated spectra (IR and Raman), NLO, AIM and molecular docking of carisoprodol from DFT approach}

\author{
Manoj Kumar Chaudhary ${ }^{1,2}$, Tarun Chaudhary ${ }^{1}$, Bhawani Datt Joshi ${ }^{3^{*}}$ \\ ${ }^{1}$ Central Department of Physics, Tribhuvan University, Kirtipur, Kathmandu, Nepal \\ ${ }^{2}$ Department of Physics, University of Lucknow, Lucknow-226007, India \\ ${ }^{3}$ Department of Physics, Siddhanath Science Campus, Tribhuvan University, Mahendranagar, 10406, \\ Nepal \\ *Email: pbdjoshi@gmail.com
}

Article Information:

Received: May 20, 2020

Accepted: June 20, 2020

Keywords:

Carisoprodol

Vibrational spectroscopy (IR

and Raman)

Molecular docking

\begin{abstract}
The aim of this study to explore the spectroscopic behavior of carisoprodol in terms of simulated spectra (IR and Raman). The intramolecular H-bond of the molecule has been inspected from the Atoms in Molecule (AIM) approach which infers that there exist partial covalent $\mathrm{H}$-bond in nature. The protein-ligand binding activity of the drug molecule has been analyzed theoretically from the molecular docking approach with the predicted targets in terms of binding energy and conventional H-bond with residue. The molecular docking analysis of the title molecule explores that the binding energy with the protein acetylcholinesterase is more than the protein epoxide hydrolase 1 . The nonlinear optical (NLO) behavior of title molecule has been scrutinized which motivates that the potent use of the molecule as NLO material.
\end{abstract}

DOI: https://doi.org/10.3126/bibechana.v18i1.29036

This work is licensed under the Creative Commons CC BY-NC License. https://creativecommons.org/licenses/by-nc/4.0/

\section{Introduction}

Carisoprodol, (RS)-2-\{[(amino carbonyl) oxy] methyl $\}$-2methyl pentyl isopropyl carbamate, with the molecular formula $\left(\mathrm{C}_{12} \mathrm{H}_{24} \mathrm{~N}_{2} \mathrm{O}_{4}\right)$ is a centrally acting skeletal muscle relaxant belonging to the BCS class II drug [1-3]. Carisoprodol is generally prescribed for the treatment of various muscular problems, mainly for lower back pain [2]. Further, it is used in the treatment of muscular spasm related to the craniomandibular disorder, lumbago, sciatica, and other lower back syndromes [4]. The anticholinergic, antipyretic, and analgesic property behavior of carisoprodol has been studied regarding the treatment of distress associated with painful musculoskeletal conditions in adults $[4,5]$.

It is triclinic in the crystalline structure lies in $\mathrm{P}_{1}$ space group with the cell dimensions $a=5.334(3)$, $\mathrm{b}=10.831(5), \mathrm{c}=13.114(5) \AA, \alpha=92.66(4), \beta=$ 96.03(4), $\gamma=92.70(4)^{\circ}$ and it is fully in extended conformations due to intramolecular $\mathrm{C}-\mathrm{H} \cdots \mathrm{O}$ hydrogen bonding [6]. To enhance the potential of drugs many pharmacological and drug behavior of 
carisoprodol has been carried out [7-9]. The structural and spectroscopic properties of this molecule at the atomic level have not been conducted so far. Therefore, in present work, an endeavor has been made to investigate the employments of the quantum computational method (applying DFT) to explore the vibrational spectra (FT-IR and FT-Raman), nonlinear optical (NLO) properties and atoms in molecule (AIM) of the molecule. Furthermore, molecular docking is performed to study hydrogen bonding and the biological activity of carisoprodol with different proteins. Ultimately, the study of different molecular properties might have great importance in designing and developing new efficient drugs in the coming days on the basis of protine ligand binding interaction [10-12].

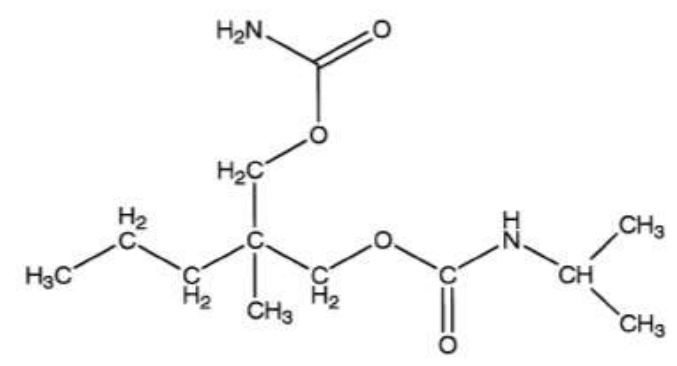

Fig. 1: Chemical structure of carisoprodol.

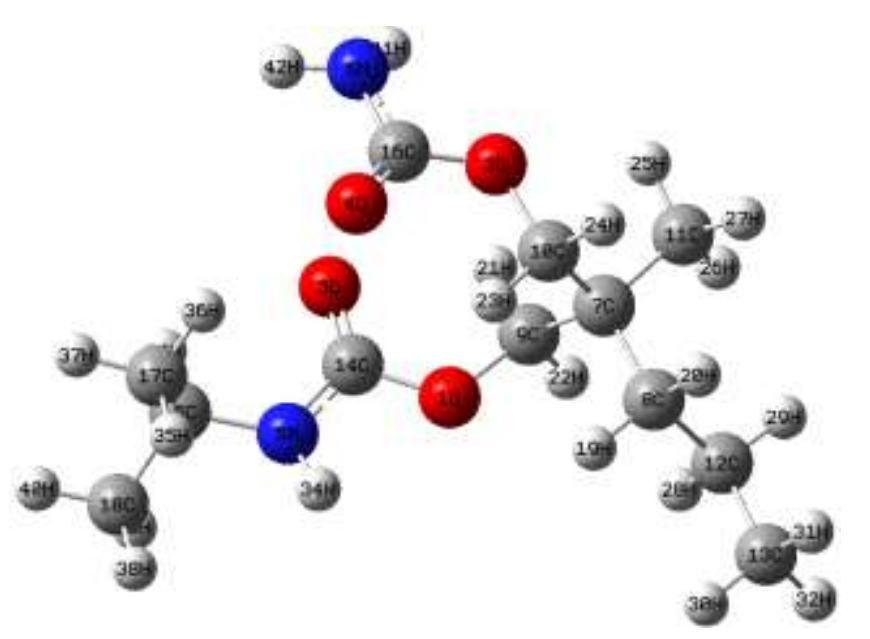

Fig. 2: Optimized structure atom numbering scheme of carisoprodol.
The chemical structure of carisoprodol is shown in Fig. 1. The optimized structure of the title molecule using functional B3LYP/6-31G(d,p) with the atom numbering system used in this study is shown in Fig. 2. The minimum energy position of the molecule has been predicted based on geometry optimization with DFT calculation by using the functional B3LYP/6-31G(d,p) which gives better agreement with the X-Ray crystal structure [13]. The optimization energy of the title compound was calculated at room temperature is - 553413.0830 $\mathrm{kcal} / \mathrm{mol}$ which is less than the value of $\mathrm{kT}$. This gives support towards the stability of the molecule at room temperature.

\section{Computational and theoretical details}

The geometry optimization of carisoprodol was performed with the Gaussian-09 software package [14]. The density functional theory (DFT) study has been performed by using the functional B3LYP/6$31 \mathrm{G}(\mathrm{d}, \mathrm{p})$ basis set $[15,16]$. The hybrid exchange functional Becke's three parameters contain local, non-local, and HF (Hartree-Fock) with Lee-YangPar correlation functional. The literature survey reveals that the result of the functional B3LYP is closer to the experimental values [17,18]. So, we have considered the functional B3LYP for the calculation. It is one of the most frequently used functional for quantum computing procedure to investigate theoretical results as supporting tools to the experimental results. The output data of Gaussian-09 has been visualized with Gauss view 05 software. The Raman intensity, Infrared absorption, and first-order hyperpolarizability were calculated at the same level of theory as optimization. The atom in the molecule (AIM) of the title molecule has been studied with AIM 2000 and AIM all software, employing Quantum theory of atoms in molecule (QTAIM) [19,20]. The molecular docking of carisoprodol has been carried out with AutoDock software and ligand-protein interaction has been visualized with bio visualizer software [21,22]. 
The Raman intensity for vibration is obtained in terms of Raman scattering cross-section, $\frac{\partial \sigma_{j}}{\partial \Omega}$, which depend on Raman amplitude and is given by the expression [23,24]

$\frac{\partial \sigma_{j}}{\partial \Omega}=\left(\frac{2^{4} \pi^{4}}{45}\right)\left(\frac{\left(v_{0}-v_{j}\right)^{4}}{1-\exp \left[\frac{h c v_{j}}{k T}\right]}\right)\left(\frac{h}{8 \pi^{2} c v_{j}}\right) S_{j}$

where $\mathrm{S}_{\mathrm{j}}=$ scattering activities, $v_{\mathrm{j}}=$ predicted wavenumbers for $\mathrm{j}^{\text {th }}$ normal mode, $v_{0}=$ wavenumber of Raman excited state and h, c and $\mathrm{k}$ are universal constants. The Lorentzian line shape (FWHM $=8 \mathrm{~cm}^{-1}$ ) is used to produce simulated spectra from the calculated Raman and IR intensities to convolute each predicted vibrational mode.

Total static dipole moment $\left(\mu_{0}\right)$, the first hyperpolarizability $\left(\beta_{0}\right)$, mean polarizability $\left(\Delta \alpha_{0}\right)$ and anisotropy of polarizability $\left|\alpha_{0}\right|$ of the molecular system were calculated by using DFT at B3LYP/6-31G(d, p) level of theory and are given by the equations $[25,26]$.

$\mu_{0}=\left(\mu_{x}^{2}+\mu_{y}^{2}+\mu_{z}^{2}\right)^{1 / 2}$

$\left|\alpha_{0}\right|=\frac{1}{3}\left(\alpha_{x x}+\alpha_{y y}+\alpha_{z z}\right)$

$\Delta \alpha=2^{-1 / 2}\left[\left(\alpha_{x x}-\alpha_{y y}\right)^{2}+\left(\alpha_{y y}-\alpha_{z z}\right)^{2}+\right.$

$\left.\left(\alpha_{z z}-\alpha_{x x}\right)^{2}+6 \alpha_{x x}^{2}\right]^{1 / 2}$

$\beta_{0}=\left[\left(\beta_{x x x}+\beta_{x y y}+\beta_{x z z}\right)^{2}+\left(\beta_{y y y}+\beta_{x x y}+\right.\right.$

$\left.\left.\beta_{y z z}\right)^{2}+\left(\beta_{z z z}+\beta_{x x z}+\beta_{y y z}\right)^{2}\right]^{1 / 2}$

\section{Results and Discussion}

\subsection{Vibrational spectra}

The carisoprodol molecule has 42 atoms so it has 120 (3N-6) modes of vibration including stretching and bending. All the normal modes of vibration are both IR and Raman active. In the calculated spectra with B3LYP, the overestimated wavenumber is obtained due to anharmonicity present in a real system. So, the wavenumber is lowered down by wavenumber linear scaling (WLS) factor [27] which gives better resonance with experimental data. The graph of calculated IR absorbance and Raman intensity of the title molecule with scaled wavenumber is plotted as shown in Fig. 3.

\subsubsection{Amine group $\left(\mathrm{NH}_{2}\right)$ vibration}

From the literature survey, the stretching of an amine group $\left(\mathrm{NH}_{2}\right)$ lies in the range between 3200$3500 \mathrm{~cm}^{-1}$ [28]. In this study, the asymmetric stretching of $\mathrm{NH}_{2}$ was calculated at $3534 \mathrm{~cm}^{-1}$ in both IR and Raman spectrum. And the symmetric stretching was calculated at $3420 \mathrm{~cm}^{-1}$ but the inplane bending is calculated at $1603 \mathrm{~cm}^{-1}$. The intense peak for $\mathrm{N}-\mathrm{H}$ stretching was at $3441 \mathrm{~cm}^{-1}$ in both IR and Raman spectrum. The C-N stretching is seen in IR and Raman spectra at $1233 \mathrm{~cm}^{-1}$ in the scaled DFT. The increase in wave number of asymmetric stretching of the amine group infers that the amine group take part in intermolecular $\mathrm{H}$ bonding with neighboring molecules in the crystalline structure. In this study, we have taken a single molecule in the gaseous state that shows some differences in the vibrational frequencies.

\subsubsection{Carbonyl group $(\mathrm{C}=\mathrm{O})$ vibration}

The stretching for carbonyl group was calculated at $1793 \mathrm{~cm}^{-1}$ in the IR and $1770 \mathrm{~cm}^{-1}$ in Raman band. From the literature, the range for stretching of the carbonyl group is $1670-1820 \mathrm{~cm}^{-1}$ [29]. The out of plane bending was calculated at $773 \mathrm{~cm}^{-1}$ and 757 $\mathrm{cm}^{-1}$ in IR and Raman spectra, respectively.

\subsection{3 $\mathrm{CH}_{2}$ and $\mathrm{CH}_{3}$ vibration}

A literature survey reveals that the range of symmetric stretching for $\mathrm{CH}_{2}$ is $3000-3100 \mathrm{~cm}^{-1}$

[30]. In this study, the intense peaks for symmetric stretching are calculated at $2894 \mathrm{~cm}^{-1}, 2930 \mathrm{~cm}^{-1}$, and $2944 \mathrm{~cm}^{-1}$ but another intense peak for asymmetric stretching for $\mathrm{CH}_{2}$ is obtained in both IR and Raman spectra at $2981 \mathrm{~cm}^{-1}$. The distinct peak for symmetric stretching of $\mathrm{CH}_{3}$ in the title molecule is obtained at $2915 \mathrm{~cm}^{-1}$. 


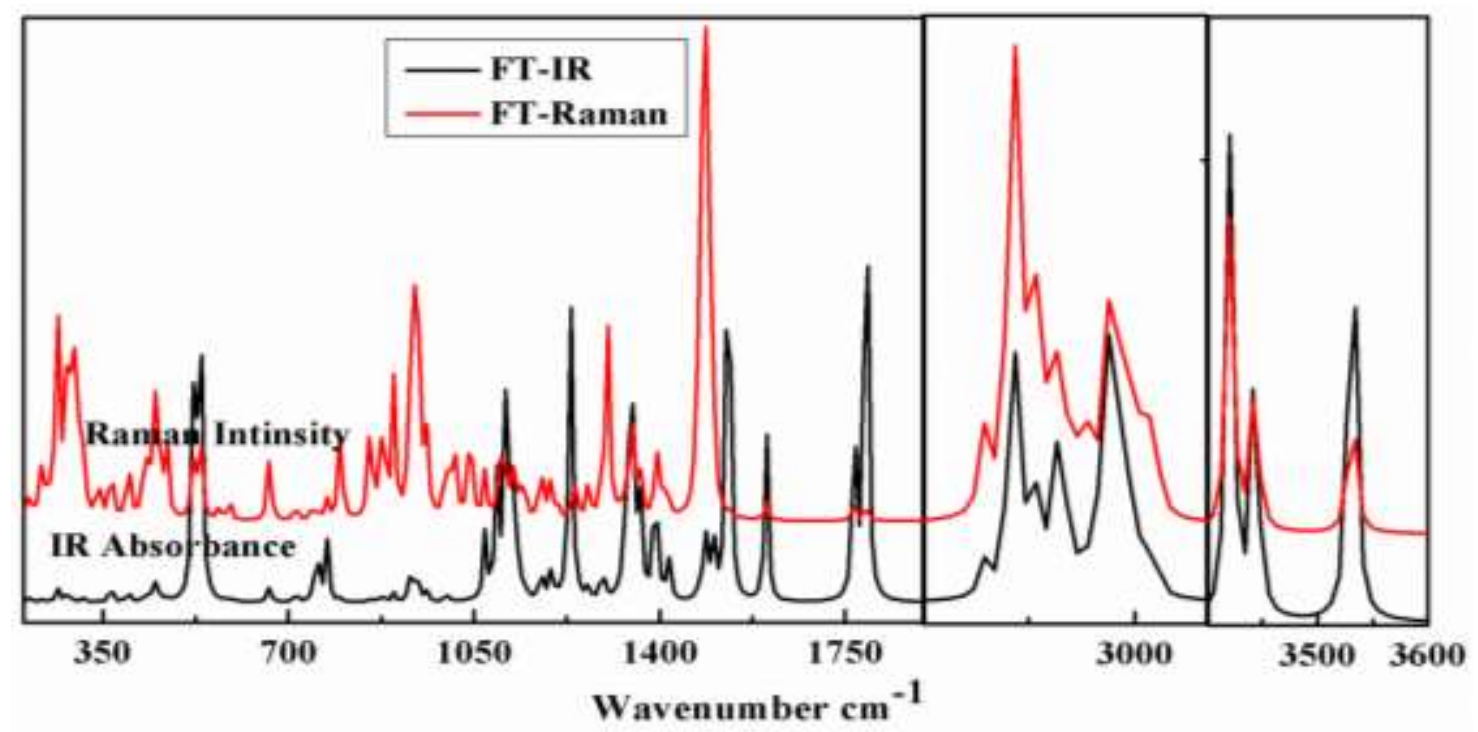

Fig. 3. Simulation of calculated IR and Raman spectra of carisoprodol.

\subsection{Nonlinear optical (NLO) properties}

The attractive potential application of NLO properties of the material is in optical communication, optical sensing, and data storage. The NLO properties of the material are explained in terms of static dipole moment $\left(\mu_{0}\right)$, the mean polarizability $(\Delta \alpha)$, the first hyperpolarizability $\left(\beta_{0}\right)$ and the anisotropy of polarizability $\left(\left|\alpha_{0}\right|\right)$. These values of carisoprodol are calculated from B3LYP/6-31G $(\mathrm{d}, \mathrm{p})$ and their values are presented in Table 1.

Table 1: The calculated dipole moment $\left(\mu_{0}\right)$, mean polarizability $\left|\alpha_{0}\right|$, anisotropy of polarizability $(\Delta \alpha)$ and first hyperpolarizability $\left(\beta_{0}\right)$ of carisoprodol at B3LYP/6-31G(d,p).

\begin{tabular}{llllll}
\hline $\begin{array}{l}\text { Dipole moment } \\
\text { (Debye) }\end{array}$ & \multicolumn{2}{l}{$\begin{array}{l}\text { Polarizability } \\
\left(* 10^{-24} \mathrm{esu}\right)\end{array}$} & \multicolumn{2}{l}{$\begin{array}{l}\text { Hyperpolarizability } \\
\left(* 10^{-30} \mathrm{esu}\right)\end{array}$} \\
\hline$\mu_{\mathrm{x}}$ & -0.8384 & $\alpha_{\mathrm{xx}}$ & 12.5980 & $\beta_{\mathrm{xxx}}$ & 0.9424 \\
$\mu_{\mathrm{y}}$ & -1.0866 & $\alpha_{\mathrm{xy}}$ & 0.5476 & $\beta_{\mathrm{xxy}}$ & 0.3385 \\
$\mu_{\mathrm{z}}$ & 0.6195 & $\alpha_{\mathrm{yy}}$ & 21.9204 & $\beta_{\mathrm{xyy}}$ & -0.5901 \\
$\mu_{0}$ & 1.5058 & $\alpha_{\mathrm{xz}}$ & -0.6665 & $\beta_{\mathrm{yyy}}$ & -0.4011 \\
$\mu_{0}($ Urea $)$ & 1.3732 & $\alpha_{\mathrm{yz}}$ & 1.6162 & $\beta_{\mathrm{xxz}}$ & 0.0089 \\
& & $\alpha_{\mathrm{zz}}$ & 19.0427 & $\beta_{\mathrm{xyz}}$ & 0.2270 \\
& & $\left|\alpha_{0}\right|$ & 17.8537 & $\beta_{\mathrm{yyz}}$ & -0.0855 \\
& & $\Delta \alpha$ & 23.3704 & $\beta_{\mathrm{xzz}}$ & -0.6754 \\
& & $\Delta \alpha(\mathrm{Urea})$ & 9.7710 & $\beta_{\mathrm{yzz}}$ & -0.2433 \\
& & & & $\beta_{\mathrm{zzz}}$ & 0.1166 \\
& & & & $\beta_{0}$ & 0.4467 \\
& & & & $\beta_{0}($ Urea $)$ & 0.3728 \\
& & & & & \\
\hline
\end{tabular}


The significant delocalization of charge in a particular direction is mentioned by the component of polarizability in that direction. The dipole moment $\left(\mu_{0}\right)$, the anisotropy of polarizability $(\Delta \alpha)$, and the first hyperpolarizability $\left(\beta_{0}\right)$ of carisoprodol obtained as 1.5058 Debye, 23.3704X10-24 esu, and $0.4467 \times 10^{-30} \mathrm{esu}$ respectively. These values are more than the experimental values of urea, so carisoprodol can be used as NLO material.

\subsection{Atoms in molecule (AIM)}

Atoms in molecules' (AIM) is the proper way to evaluate the inter and intramolecular H-bonding. The quantum theory of atoms in molecules (QTAIM) has wide application for identification and classification of $\mathrm{H}$-bonding in terms of electron density $(\rho)$ and Laplacian of electron density $\left(\nabla^{2} \rho\right)$ at the bond critical point (BCP). The molecular graph of carisoprodol by using the functional B3LYP/6-31G(d,p) with AIM 2000 and AIM All software is presented in Fig. 4. The topological parameters: $\mathrm{ED}\left(\rho_{\mathrm{BCP}}\right)$, Laplacian of $\mathrm{ED}\left(\nabla^{2} \rho_{\mathrm{BCP}}\right)$, electron kinetic energy density $\left(\mathrm{G}_{\mathrm{BCP}}\right)$, electron potential energy density $\left(\mathrm{V}_{\mathrm{BCP}}\right)$, total electron energy density $\left(\mathrm{H}_{\mathrm{BCP}}\right)$, interaction energy $\left(\mathrm{E}_{\text {int }}\right)$ at
BCP; in carisoprodol is presented in Table 2. The geometrical parameters, bond length, bond angle, and the sum of van der Waal radii of interacting atoms $\left(\mathrm{r}_{\mathrm{H}}+\mathrm{r}_{\mathrm{A}}\right)$ is visualized in Table 3 .

In the carisoprodol molecule, four intramolecular H-bond has been observed and they have the electron density $(\rho)$ between proton $(H)$ and acceptor (A) in the order $0.002-0.040$ a.u. and the Laplacian $\left(\nabla^{2} \rho_{\mathrm{BCP}}\right)$ of electron density lies in the order $0.024-0.139$ a.u. These values are in the range proposed by Koch and Popelier [31] for the existence of $\mathrm{H}$-bond. For the investigated molecule it has been identified that $\left(\nabla^{2} \rho_{\mathrm{BCP}}\right)>0$ and $\left(\mathrm{H}_{\mathrm{BCP}}\right)<$ 0 , so the $\mathrm{H}$-bond is partially covalent as given by Rosa et al. criteria [32]. But for strong H-bond and weak H-bond, the criteria given by Rosa et al. are $\left(\nabla^{2} \rho_{\mathrm{BCP}}\right)<0$ and $\left(\mathrm{H}_{\mathrm{BCP}}\right)<0$, and $\left(\nabla^{2} \rho_{\mathrm{BCP}}\right)>0$ and $\left(\mathrm{H}_{\mathrm{BCP}}\right)>0$ respectively. Out of the four $\mathrm{H}$-bond, the interaction $\mathrm{C} 9-\mathrm{H} 21 \ldots \mathrm{O} 3$ has the highest values of electron density, Laplacian of electron density, and interaction energy as presented in Table 2,

So it is the strongest interaction. This interaction is similar as explained by Horio et al. [6].

Table 2: Topological parameters for intramolecular interaction in carisoprodol: ED ( $\left.\rho_{\mathrm{BCP}}\right)$, Laplacian of $\mathrm{ED}\left(\nabla^{2} \rho_{\mathrm{BCP}}\right)$, electron kinetic energy density $\left(\mathrm{G}_{\mathrm{BCP}}\right)$, electron potential energy density $\left(\mathrm{V}_{\mathrm{BCP}}\right)$, total electron energy density $\left(\mathrm{H}_{\mathrm{BCP}}\right)$, interaction energy $\left(\mathrm{E}_{\mathrm{int}}\right)$ at $\mathrm{BCP}$.

\begin{tabular}{llllllll}
\hline Interactions & $\begin{array}{l}\text { Bond } \\
\text { Length }(\AA)\end{array}$ & $\begin{array}{l}\rho_{\mathrm{BCP}} \\
(\mathrm{a} . \mathrm{u})\end{array}$ & $\begin{array}{l}\nabla^{2} \rho_{\mathrm{BCP}} \\
(\mathrm{a} . \mathrm{u})\end{array}$ & $\begin{array}{l}\mathrm{G}_{\mathrm{BCP}} \\
(\mathrm{a} . \mathrm{u})\end{array}$ & $\begin{array}{l}\mathrm{V}_{\mathrm{BCP}} \\
(\mathrm{a} . \mathrm{u})\end{array}$ & $\begin{array}{l}\mathrm{H}_{\mathrm{BCP}} \\
(\text { a.u })\end{array}$ & $\begin{array}{l}\mathrm{E}_{\text {int }} \\
(\mathrm{kcal} / \mathrm{mol})\end{array}$ \\
\hline $\mathrm{H} 36 \ldots \mathrm{O} 4$ & 2.5062 & 0.0085 & 0.0276 & -0.0006 & -0.0056 & -0.0063 & -1.4828 \\
$\mathrm{H} 21 \ldots \mathrm{O} 3$ & 2.2215 & 0.0203 & 0.0850 & -0.0024 & -0.0164 & -0.0189 & -4.3367 \\
$\mathrm{C} 16 \ldots \mathrm{O} 3$ & 3.1270 & 0.0059 & 0.0239 & -0.0012 & -0.0036 & -0.0048 & -0.9414 \\
$\mathrm{H} 28 \ldots \mathrm{H} 22$ & 2.2443 & 0.0084 & 0.0347 & -0.0021 & -0.0044 & -0.0066 & -1.1719 \\
\hline
\end{tabular}

Table 3: Geometrical parameters for intramolecular hydrogen bonds in carisoprodol: bond length $(\AA)$, bond angle $\left({ }^{\circ}\right)$, and the sum of van der Waal radii of interacting atoms $\left(\mathrm{r}_{\mathrm{H}}+\mathrm{r}_{\mathrm{A}}\right)$ in $\AA$.

\begin{tabular}{lllll}
\hline \multicolumn{1}{c}{ D-H...A } & D-H $(\AA)$ & H...A $(\AA)$ & D-H...A $\left({ }^{\circ}\right)$ & $\left(\mathrm{r}_{\mathrm{H}}+\mathrm{r}_{\mathrm{A}}\right)(\AA)$ \\
\hline $\mathrm{C} 17-\mathrm{H} 36 \ldots \mathrm{O} 4$ & 1.0931 & 2.5062 & 159.1608 & 2.72 \\
$\mathrm{C} 9-\mathrm{H} 21 \ldots \mathrm{O} 3$ & 1.0905 & 2.2215 & 105.8896 & 2.72 \\
$\mathrm{~N} 6-\mathrm{C} 16 \ldots \mathrm{O} 3$ & 1.3684 & 3.1270 & 90.2495 & 3.22 \\
$\mathrm{C} 12-\mathrm{H} 28 \ldots \mathrm{H} 22$ & 1.0971 & 2.2443 & 113.4188 & 2.40 \\
\hline
\end{tabular}




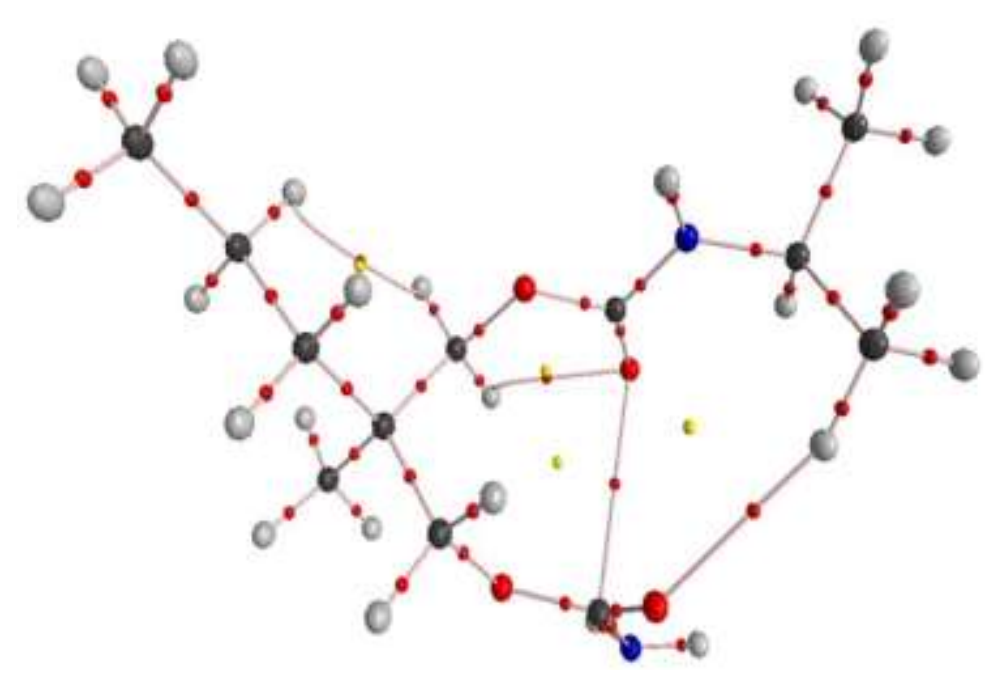

Fig. 4. Molecular graph of carisoprodol obtained by AIM.

\subsection{Molecular docking}

Molecular docking is a fundamental tool, which predicts the non-covalent binding of a receptor. It is used to study the protean-ligand binding affinity of bound conformations. To predict the active binding sites of carisoprodol, a docking study was performed using AutoDock-Vina software [21]. The proteins epoxide hydralase1 and acetylcholinesterase were predicted with online Swiss Target Prediction as shown in Fig. 5. The crystal structure of epoxide hydrolase with PDB code; 4XDV, 4XDW, and acetylcholinesterase with PDB code; 2ACE, 2V96 were downloaded from RSCB PDB website. Epoxide hydralase1 is an enzyme that is mainly found in the endoplasmic reticulum. It has curative behavior to metabolize reactive epoxide to less toxic water-soluble diols [33,34]. Protein acetylcholinesterase is mainly found in the central nervous system having curative behavior to terminate nerve impulse and prevents nerve firing at the nerve ending and assists in the normal functioning of the central and peripheral nervous system [35].
The protein was prepared by removing water molecules and crystallized ligand from it. Further, polar hydrogen and Kollman charges were added to the protein using AutoDock tools. The active site of protein was confined in the grid box of size $60 \AA \times 60 \AA \times 60 \AA$ with the spacing of $0.347 \AA$. Biovia Discovery studio 2020 was used for visualization of AutoDock-Vina result. The protein-ligand interaction of docked conformers is presented in Fig. 6 . The calculated value of binding energy, the number of hydrogen bonds, and active binding residues are tabulated in Table 4. Out of four docked conformations, 2V96 showed the best binding energy $-6.6 \mathrm{kcal} / \mathrm{mol}$ which binds with residue SER B:286 (2.77 A and $2.82 \AA$ ). Similarly, the conformer $2 \mathrm{ACE}$ of acetylcholinesterase bind with carisoprodol and gives three hydrogen bond (2.54 A, ASP A:72, and 3.02/2.71 A, TYRA:121) with the binding energy $-6.5 \mathrm{kcal} / \mathrm{mol}$. From this study, it is observed that the amine group and carbonyl group behave as active binding sites which is also explored in the section 3.1.1. 
Table 4: Bond length, and binding energy of carisoprodol against two protein targets.

\begin{tabular}{|c|c|c|c|c|c|c|}
\hline Ligand & Protein & $\begin{array}{l}\text { PDB } \\
\text { code }\end{array}$ & $\begin{array}{l}\text { Binding } \\
\text { energy } \\
\text { (kcal/mol) }\end{array}$ & $\begin{array}{l}\text { Bond } \\
\text { Length }(\AA)\end{array}$ & Amino acid & $\begin{array}{l}\text { No. of } \\
\text { hydrogen } \\
\text { bond }\end{array}$ \\
\hline \multirow{4}{*}{ Carisoprodol } & \multirow{2}{*}{$\begin{array}{l}\text { Epoxide } \\
\text { Hydrolase1 }\end{array}$} & $4 \mathrm{XDV}$ & -6.1 & $\begin{array}{l}3.08(\mathrm{O} 3) \\
3.09(\mathrm{O} 3) \\
2.09(\mathrm{H} 41) \\
2.74(\mathrm{H} 42) \\
2.37(\mathrm{H} 42)\end{array}$ & $\begin{array}{l}\text { ASN G:92 } \\
\text { SER G:91 } \\
\text { SER G:90 } \\
\text { GLU G:25 } \\
\text { SER H:91 }\end{array}$ & 5 \\
\hline & & 4XDW & -5.7 & $\begin{array}{l}2.81(\mathrm{H} 42) \\
2.83(\mathrm{H} 41) \\
3.13(\mathrm{O} 4) \\
2.99(\mathrm{O} 3)\end{array}$ & $\begin{array}{l}\text { TYR B:53 } \\
\text { PRO B:59 } \\
\text { ASN B:55 } \\
\text { THR B:70 }\end{array}$ & 4 \\
\hline & \multirow{2}{*}{$\begin{array}{l}\text { Acetylcholi- } \\
\text { nesterase }\end{array}$} & $2 \mathrm{ACE}$ & -6.5 & $\begin{array}{l}2.54(\mathrm{H} 42) \\
3.02(04) \\
2.71(\mathrm{O} 1)\end{array}$ & $\begin{array}{l}\text { ASP A:72 } \\
\text { TYRA:121 } \\
\text { TYRA:121 }\end{array}$ & 3 \\
\hline & & 2V96 & -6.6 & $\begin{array}{l}2.77(\mathrm{H} 42) \\
2.82(\mathrm{H} 34)\end{array}$ & $\begin{array}{l}\text { SERB:286 } \\
\text { SERB:286 }\end{array}$ & 2 \\
\hline
\end{tabular}

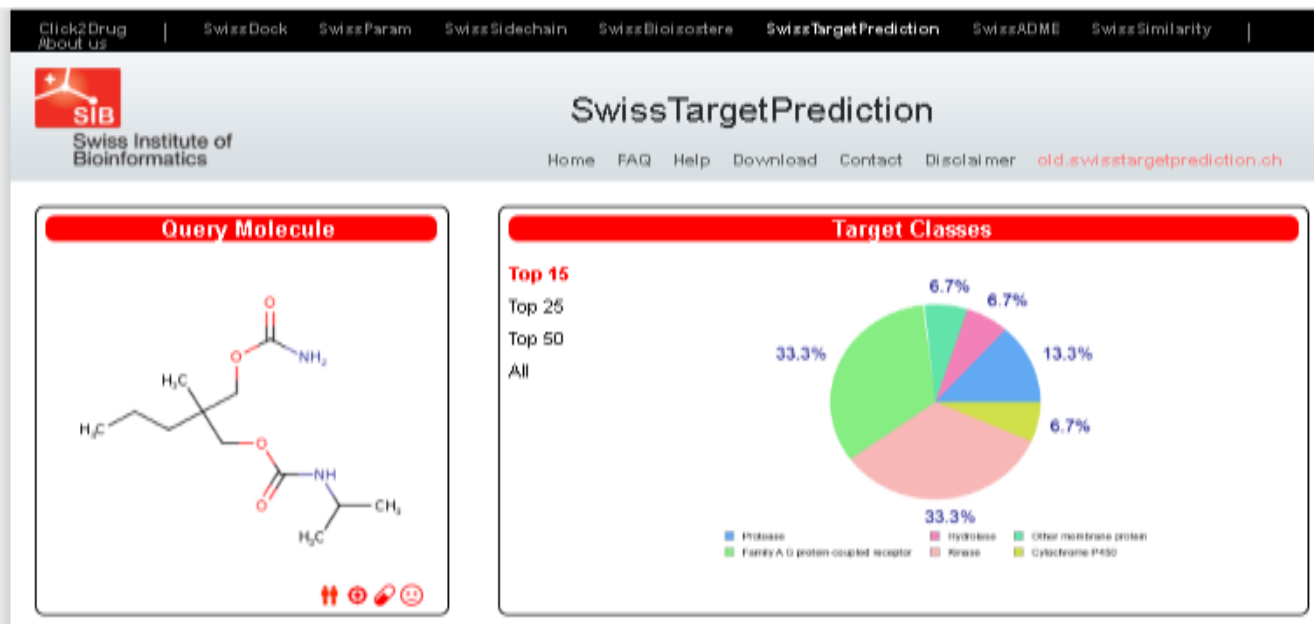

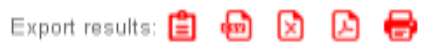

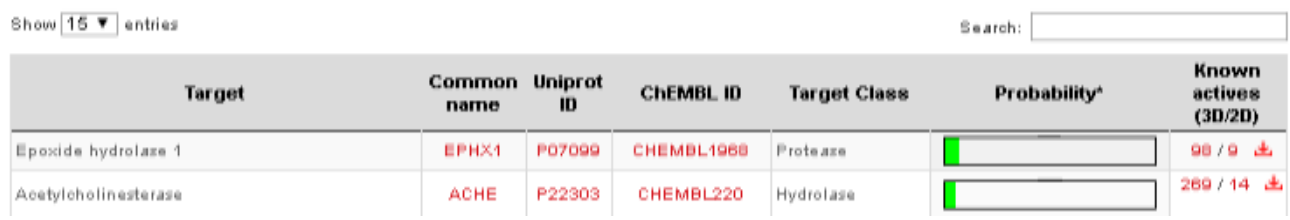

Fig. 5: Swiss Target Prediction of carisoprodol. 


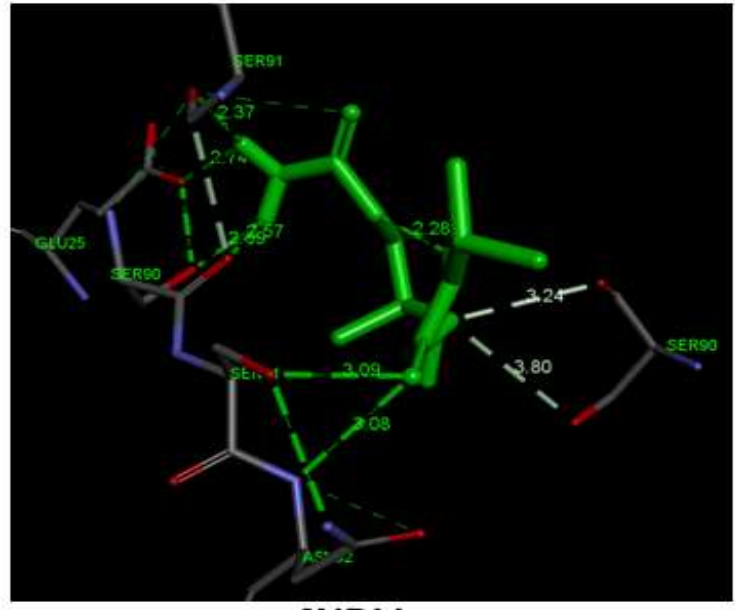

4XDV

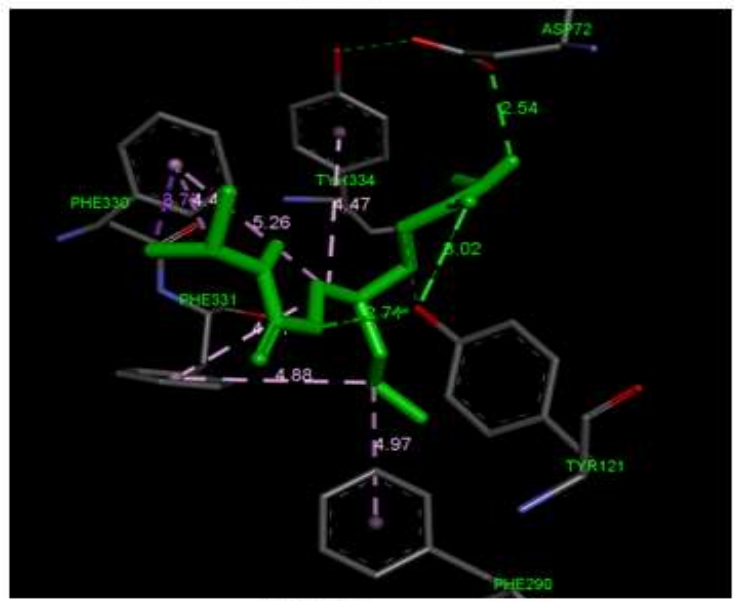

2ACE

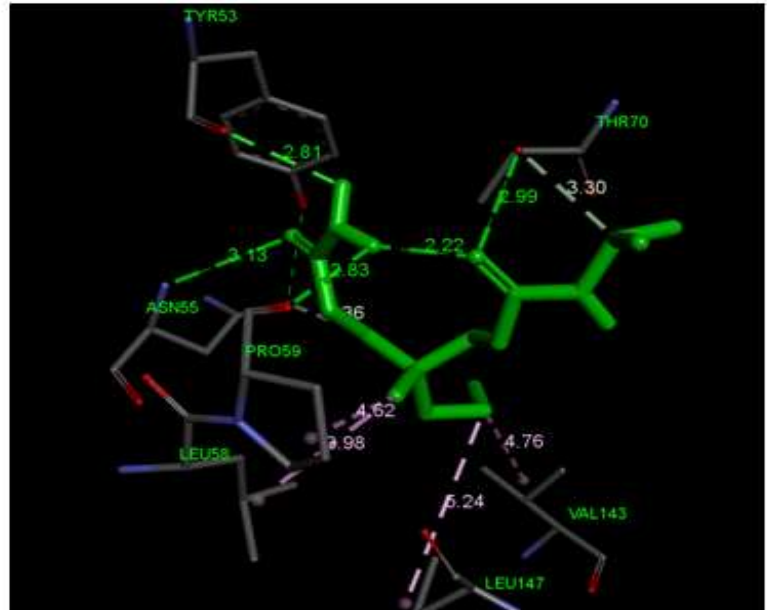

4XDW

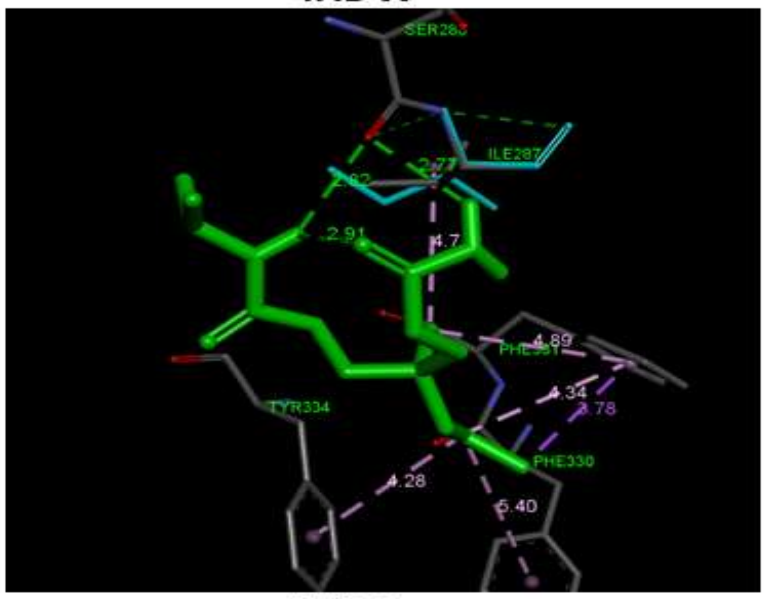

2V96

Fig. 6: Molecular docking of carisoprodol.

\section{Conclusions}

From the simulated IR and Raman spectra of the title molecule, it is observed that functional groups: carbonyl $(\mathrm{C}=\mathrm{O})$, amine $\left(\mathrm{NH}_{2}\right), \mathrm{CH}_{2}$, and $\mathrm{CH}_{3}$ vibrations are in the range given by the literature survey. The dipole moment $\left(\mu_{0}\right)$, polarizability $(\Delta \alpha)$, and first hyperpolarizability $\left(\beta_{0}\right)$ of carisoprodol are $1.5058 \mathrm{D}, 23.3704 \times 10^{-24} \mathrm{esu}$, and $0.4467 \times 10^{-30} \mathrm{esu}$, respectively. These values are more than the experimental values of urea (taken as a standard NLO material), so this material can be treated as NLO material besides the medicinal properties. The outcome of the AIM study of investigated molecule showed four intermolecular H-bonds which are partially covalent. Among them, the interaction $\mathrm{C} 9-\mathrm{H} 21 \ldots \mathrm{O} 3$ is the strongest due to the highest interaction energy $\left(E_{\text {int }}=-\right.$ 4.3367) at BCP. The molecular docking studies reveal good binding with acetylcholinesterase protein, PDB code: 2 V96 with a binding energy of $-6.6 \mathrm{kcal} / \mathrm{mol}$.

\section{References}

[1] R.R. Reeves, O.S. Carter, H.B. Pinkofsky, F.A. Struve, D.M. Bennett, Carisoprodol (Soma) Abuse Potential and Physician Unawareness, J. Addict. Dis. 18 (1999) 51-56. https://doi.org/10.1300/J069v18n02_05 
[2] J.G. Bramness, S. Skurtveit, J. Mørland, Impairment due to intake of carisoprodol, Drug Alcohol Depend, 74 (2004) 311-318. https://doi.org/10.1016/j.drugalcdep.2004.01.007

[3] V.G. Rajurkar, S.K. Somware, A. Aher, V. Pansare, Tablet formulation and enhancement of aqueous solubility of carisoprodol by solvent evaporation cocrystal technique, Anal. Chem. Lett.5 (2015) 364-376. https://doi.org/10.1080/22297928.2015.1129288

[4] K. A. Kumar, V.S. Lakshmipathi, S. Meenakshi, M.H. Balakrishnan, Synthesis and Characterization of Potential Impurity of Muscle Relaxant Drug Carisoprodol, J. Chem. Sci. 7 (4) (2017) 352-360.

Www.chemistry-journal.org

[5] M.B. Bolattin, S.T. Nandibewoor, S.D. Joshi, S.R. Dixit, S.A. Chimatadar, Interaction between carisoprodol and bovine serum albumin and effect of $\beta$-cyclodextrin on binding: insights from molecular docking and spectroscopic techniques, RSC Adv. 6 (2016) 63463-63471. https://doi.org/10.1039/C6RA08063D

[6] K. Horio, R. Tanaka, H. Akama, M. Haramura, A. Tanaka, T. Akimoto, N. Hirayama, Crystal Structure of Carisoprodol, Anal. Sci.: X-ray Structure Analysis Online, 20 (2004) x43-x44. https://doi.org/10.2116/analscix.20.x43

[7] S. Niemi, Muscle Relaxants and Antispasticity Drugs, In: Abd-Elsayed A. (eds) Pain, Springer, Cham. (2019) 279-283. https://doi.org/10.1007/978-3-319-99124-5 61

[8] Y. Li, C. Delcher, J. D. Brown, Y. J. Wei, G. M. Reisfield, A. G. Winterstein, Impact of Schedule IV controlled substance classification on carisoprodol utilization in the United States: An interrupted time series analysis, Drug Alcohol Depend. 202 (2019)172-177. https://doi.org/10.1016/j.drugalcdep.2019.05.025

[9] T. M. Carbonaro, V. Nguyen, M. J.Forster, M. B. Gatch, L. Prokai, Carisoprodol pharmacokinetics and distribution in the nucleus accumbens correlates with behavioral effects in rats independent from its metabolism to meprobamate, Neuropharmacol. (2020) 108152. https://doi.org/10.1016/j.neuropharm.2020.10815 $\underline{2}$

[10] P. Taslimi, Y. Erden, S. Mamedov, L. Zeynalova, N. Ladokhina, R. Tas, B. Tuzun, A. Sujayev, N.Sadeghian, S.H. Alwasel, I. Gulcin, The Biological Activities, Molecular Docking Studies, and Anticancer Effects of 1Arylsuphonylpyrazole Derivatives, J Bio. Mol. Struct. Dyn (2020) 1-20. https://doi.org/10.1080/07391102.2020.1763838

[11] S. Bal, R. Kaya, P. Taslimi, A. Aktaş, M. Karaman, İ. Gulçin, Novel 2-methylimidazolium salts: synthesis, characterization, molecular docking, and carbonic anhydrase and acetylcholinesterase inhibitory properties, Bioorg. Chem. $94 \quad$ (2020) 103468. https://doi.org/10.1016/j.bioorg.2019.103468.

[12] J. C. Prasana, S. Muthu, C. S. Abraham, Molecular docking studies, charge transfer excitation and wave function analyses (ESP, ELF, LOL) on valacyclovir: a potential antiviral drug, Comput. Biol. Chem. 78 (2019) 9-17. https://doi.org/10.1016/j.compbiolchem.2018.11.0 $\underline{14}$

[13] L. A. Anthony, D. Rajaraman, M. Shanmugam, K. Krishnasamy, Synthesis, Spectral techniques, X-ray Crystal structure, DFT method, Hirshfeld surface analysis and Molecular docking studies of 1-(furan-2-yl) methyl)-4, 5-diphenyl-2-(p-tolyl)1H-imidazole, Chem. Data Collect.

(2020) 100421 :https://doi.org/10.1016/j.cdc.2020.100421

[14] M.J. Frisch, G.W. Trucks, H.B. Schlegel, G.E. Scuseria, J.R. Cheeseman, M.A. Robb, G. Scalmani, V. Barone, B. Mennucci, G.A Petersson, H. Nakatsuji, M. Caricato, X. Li, H.P. Hratchian, A.F. Izmzylov, J. Bloino, G. Zheng, J.L. Sonnenberg, M. Hada, M. Ehara, K. Toyota, R. Fukuda, J. Ishida, M. Hasegawa, T. Nakajima, Y. Honda, O. Kitao, H. Nakai, T. Vreven, J.A Montgomery Jr., J.E. Peralta, F. Ogliaro, M. Bearpark, J.J. Heyd, E. Brothers, K.N. Kudin, V.N. Staroverov, R. Kobayashi, J. Normand, A. Raghavachari, A. Rendell, J.C. Burant, S.S Iyengar, J. Tomasi, M. Cossi, N. Rega, J.M Millan, M. Klene, J.E. Knox, J.B. Cross, V. Bakken, C. Adamo, J. Jaramillo, R. Gomperts, R.E. Stratmann, O. Yazyev, A.J. Austin, R. Cammi, C. Pomelli, J.W. Ochterski, R.L. Martin, K. Morokuma, V.G. Zakrzewski, G.A.Voth, P. Salvador, J.J. Dannerberg, S. Dapprich, A.D. Daniels, J. Farkas, B. Foresman, J.V. Ortiz, J. Cioslowski, D.J. Fox, GAUSSIAN 09, Revision, Gaussian, Inc., Wallingford CT, (2009).

[15] A. D. Becke, A new mixing of Hartree-Fock and local density-functional theories, J. Chem. Phys. 98 (2) (1993) 1372-1377. https://doi.org/10.1063/1.464304

[16] R.G. Parr, W. Yang, Density Functional Theory of Atoms and Molecules, Oxford, New York, (1989). https://doi.org/10.1002/qua.560470107

[17] P. Prajapati, J. Pandey, M.R. Shimpi, A. Srivastava, P. Tandon, S.P. Velaga, K. Sinha, J. Mol. Struct. $1125 \quad$ (2016) 193-203. https://doi.org/10.1016/j.molstruc.2016.06.070

[18] J. Pandey, P. Prajapati, M. R.Shimpi, P.Tandon, S. P. Velaga, A. Srivastava, K. Sinha, Studies of 
molecular structure, hydrogen bonding and chemical activity of a nitrofurantoin-L-proline cocrystal: a combined spectroscopic and quantum chemical approach, RSC Adv. 6(78) (2016) 74135-74154. doi:https://doi.org/10.1039/C6RA13035F

[19] T.A. Keith, AIMALL Version 090201 TK Gristmill Software Overland Park, KS. USA; (2009).

[20] R.F.W. Bader, Atoms in Molecules, A Quantum Theory, Oxford University Press, Oxford, (1990).

[21] O. Trott, A.J. Olson, AutoDock Vina: improving the speed and accuracy of docking with a new scoring function, efficient optimization, and multithreading, J. Comput. Chem. 31 (2010) 455461.

https:// doi.org/10.1002/jcc.21334

[22] Discovery Studio 4.5 Guide, Accelrys Inc., San Diego, http://www.accelrys.com, 2009.

[23] G.A. Guirgis, P. Klaboe, S. Shen, D.L. Powell, A. Gruodis, V. Aleksa, C.J. Nielsen, J.

[24] Tao, C. Zheng, J.R. Durig, Spectra and structure of silicon-containing compounds. XXXVIRaman and infrared spectra, conformational stability, ab initio calculations and vibrational assignment of ethyldibromosilane, J. Raman Spectrosc. $\quad 34 \quad$ (2003) 322-336. https://doi.org/10.1002/jrs.989

[25] P.L. Polavarapu, Ab initio vibrational Raman and Raman optical activity spectra, J. Phys. Chem. 94 (1990) 8106-8112. https://doi.org/10.1021/j100384a024

[26] B.D. Joshi, M.K. Chaudhary, NBO, nonlinear optical and thermodynamic properties Of10-Acetyl-10H-phenothiazine5oxide, BIBECHANA $15 \quad 31-139$ (2018). https://doi.org/10.3126/bibechana.v15i0.18385

[27] F. Weinhold, C.R. Landis, Valency and Bonding: A Natural Bond Orbital Donor- Acceptor Perspective, Cambridge University Press, Cambridge, 2005.

[28] H. Yoshida, K. Takeda, J. Okamura, A. Ehara, H. Matsurra, A new approach to vibrational analysis of large molecules by density functional theory: wavenumber-linear scaling method, J. Phys. Chem. $\quad 106 \quad$ (2002) 3580-3586. https://doi.org/10.1021/jp013084m
[29] A. Prabakaran, S. Muthu, "Normal Coordinate Analysis and Vibrational Spectroscopy (FT-IR and FT-Raman) Studies of (2S)-2-Amino-3-(3,4Dihydroxyphenyl)-2-ethylpropnoic Acid Using ab Initio HF and DFT Method," Spectrochim. Acta Part A. 99 (2012) 90-96. https://doi.org/10.1016/j.saa.2012.09.014

[30] R.M. Silverstein, G.C. Bassler, T.C. Morrill, Spectrometric identification of organic compounds. 4th ed. John Wiley and Sons, New York, 1981.

[31] H.S. Barbara, University of Technology, Sydney, Australia, Infrared Spectroscopy: Fundamentals and Applications. https://doi.org/10.1002/0471238961.09140618101 51405.a01.pub2

U. Koch, P. Popelier, Characterization of $\mathrm{CHO}$ hydrogen bonds on the basis of the charge density, J. Phys. Chem. A 99 (24) (1995) 97479754.

https://doi.org/10.1021/j100024a016

[32] I. Rozas, I. Alkorta, Elguero, Behavior of ylides containing $\mathrm{N}, \mathrm{O}$, and $\mathrm{C}$ atoms as hydrogen bond acceptors, J. Am. Chem. Soc. 122 (45) (2000) 11154-11161. https://doi.org/10.1021/ja0017864

[33] C. Hassett, L. Alcher, J.S. Sidhu, C.J. Omieclnskl, Human microsomal epoxide hydrolase: genetic polymorphism and functional expression in vitro of amino acid variants, Hum. Mol. Genet. 3 (1994) 421-428. https://doi.org/10.1093/hmg/3.3.421

[34] R. Vaclavíkova, D.J. Hughes, P. Soucek, Microsomal epoxide hydrolase 1 (EPHX1): Gene, structure, function, and role in human disease, Gene $571 \quad$ (2015) 1-8. https://doi.org/10.1016/j.gene.2015.07.071

[35] M.G. Lionetto, R. Caricato, A. Calisi, M.E. Giordano, T. Schettino, Acetylcholinesterase as a biomarker in environmental and occupational medicine: new insights and future perspectives, BioMed Res. Int. (2013). http://dx.doi.org/10.1155/2013/321213 